\title{
地方圈における買物消費額流動の変化とその要因に関する分析 \\ Change in Money Flow of Shopping Consumption \\ and its Factors in Local Region
}

\author{
近藤光男 ${ }^{*}$, 花岡憲司 ${ }^{* *}$, 廣瀬義伸 ${ }^{* * *}$, 青木 聡 ${ }^{* *}$ \\ By Akio Kondo, Kenji Hanaoka, Yoshinobu Hirose and Satoru Aoki
}

\section{1.はじめに}

国民の消費水準の向上とともに買物需要は増大かつ多様 化している。地方圈においては、郊外立地型の大規模商業 施設の増加の影響を受けて空洞化が進んでいる都市内の商 店街が少なくない。また、中山間地域においては商業施設 が質量ともに十分とは言えず、買物のためにかなりの移動 を強いられる住民が多く存在しているばかりか、交通弱者 にとっては日常生活において買物が大きな負担になってい る場合もある。今後も交通施設整備の進展や買物客に対す るサービスの向上により、地域全体での買物行動の変化が 予想される。

このような背景から、消費者の近年の買物行動の変化を 把握するとともに買物行動に及ぼす影響要因を明らかにし、 それに基づいて今後の商業環境整備を検討していくことは、 地方自治体のみならず商業経営者にとって重要な課題であ る。そこで本研究では、住民の買物行動を買物消費額の流 動によってとらえ、先述のような変化がみられる地方圈に おいて、品目別の買物消費額流動や商圈がどのように変化 しているのかを明らかにする。さらに買物消費額の流動モ デルを用いて、買物消費額の流動に影響を及ぼす要因を把 握した後、その変化の分析を行う。買物消費額流動の影響 要因には、商業施設そのものの魅力度や商業施設までの交 通利便性などがあげられるが、本研究ではこれらの要因の 影響度の変化についても分析を行う。なお、ここで言う買 物消費額の流動とは、消費者の居住地から買物を行った商 業地への買物消費額の流れを意味するものである。

\section{2. 分析対象地域と買物調查 ${ }^{1 ） 2 ） ~}$}

ケーススタディの対象地域には日本における典型的な地 方圈の 1 つである徳島県を選んだ。徳島県は 50 市町村から なり、総人口は約 83 万人である。県庁所在都市の徳島市は、

キーワード : 買物消費額, 商圈, 消費額流動モデル *正会員 工博 徳島大学大学院工学研究科教授 **学生会員 徳島大学大学院エコシステム工学専攻 ***正会員 工修 徳島大学工学部建設工学科助手 ( $7770-8506$ 徳島市南常三島町 2-1 徳島大学大学院工学研究科 TEL:088-656-7339 FAX:088-656-7341)
政治、経済、文化等の中心地であり、約 26 万人の人口をも つ。本研究では、先に述べた目的を達成するために、市町 村を単位として分析を行う。

地方圈では、大都市と比較して、店舗数が少なく、地域 の商業中心都市にその立地が集中していることに加え、商 業地にアクセスするための公共交通機関が不便であり、都 市域における商業環境と大きな違いがみられる。また、住 民の生活圈としてもかなりの広がりがみられる地方圏にお いては、消費者の居住地分布は町村の中心地などにある程 度集約されている。このような地理的な条件を背景にして、 日常生活において重要な買物環境を、圈域全体でのバラン スも考慮しながら、今後どのように整備すべきかを検討す るためには、市町村を単位として、地域住民の買物行動を 把握することがまず必要であると考えた。

本研究では、買物行動を表すデータとして、1989 年と 1996 年の「徳島県商業コミュニティプラン事業報告書」で報告 されている各年の 1 年間の買物における 13 品目別の買物消 費額の流動データを用いる。具体的には、居住地ゾーンと して市町村を設定し、各市町村における住民の品目別の消 費総額に対する買物が行われた商業地での消費額の比率で ある。この比率を百分率（\%）表示したものを、各市町村 における買物消費額の買物先比率 (以下では、単に買物先 比率とも記す）と定義する。買物先比率に関するデー夕は、 徳島県全域で 1989 年 9 月と 1996 年 7 月に行われた「商業 コミュニティ調查」と題した買物実態調查結果の市町村別 の集計結果から得られている。

\section{3. 買物消費額の流動と地域における商業の核}

各市町村の住民の買物消費額が当該市町村以外でどの程 度使われているか、つまり買物消費額の流動状況を明らか にする。ところで、ある居住地としての市町村に着目した 場合、当該市町村から他の商業地一の買物消費額の流れは、 買物消費額が流出しているとみることができる。そこで、 先に定義した買物先比率のうち、買物先として自市町村を 除くと、この比率は買物消費額の他市町村への流出比率と してとらえることができる。そこで、この視点に立ち、対 象地域内の各市町村における全品目の買物消費額の流出比 率を図一 1 と図一 2 に示す。図一 1 に示した 1989 年と図一 
2 の 1996 年の状況とを比較すると、まず、各市町村から徳 島市への流出については大きな変化はみられない。徳島市 へ 30\%以上流出しているのは、1989 年、1996 年ともに近隣 の 2 町村のみである。徳島市への流出比率が $5 \%$ 以上とな っている市町村は広く県下に広がっているが、県西部の町 村は $5 \%$ 未満で徳島市の商圈からの独立性が高いと考えら れる。また、1989 年に比べ1996 年では、他市町村から鴨島 町、阿南市、脇町などへの流出比率が増加している。中で も、阿南市一の流出比率の増加が目立ち、県中央部および 県南部の多くの町村から $20 \%$ 以上の流出比率の増加となっ ている。全体的にみると、多くの市町村で流出比率が増加 している。

以上の結果より、対象地域には商業の核となっている市 町が存在していることがわかる。以下の分析では、買物消 費額の流動をすべての市町村から商業の核となっている市 町への流動としてとらえることとし、商業の中心地として、 徳島市、鳴門市、小松島市、阿南市、鴨島町、脇町、池田 町を選んだ。これら7市町を選定した理由としては、上述 の分析結果に加え、1994 年の小売り商店年間販売額に基づ

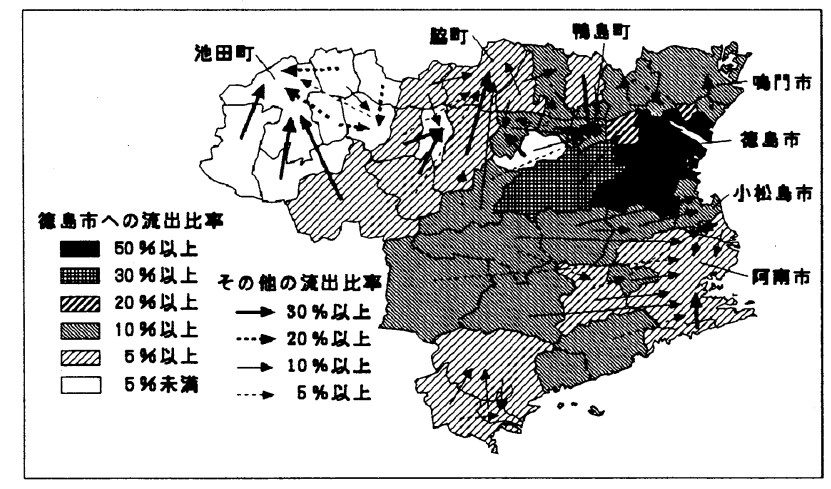

図-1 各市町村における買物消費額の流出比率（1989 年）

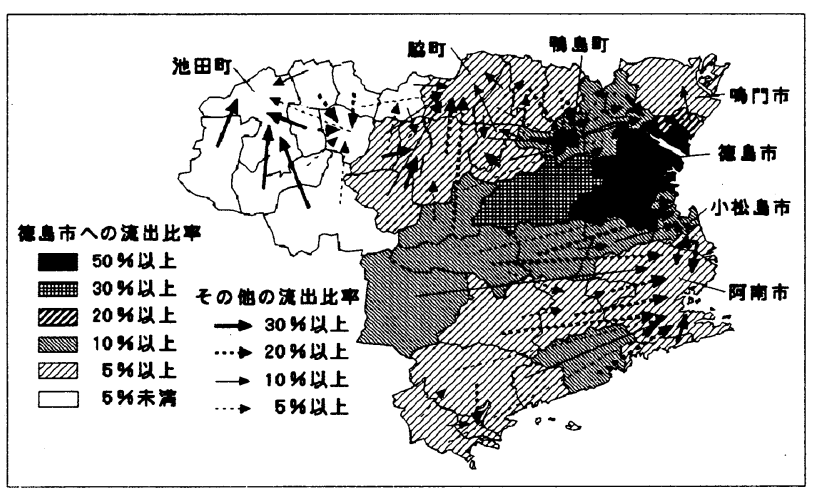

図-2 各市町村における買物消費額の流出比率（1996 年）

表 -1 買物品目の分類

\begin{tabular}{|c|c|c|c|c|}
\hline グループ1 & 生鮮食料品 & \multicolumn{3}{|l|}{ 一般食料品 } \\
\hline グループ 2 & $\begin{array}{l}\text { 医薬品 } \\
\text { 化粧品 }\end{array}$ & $\begin{array}{l}\text { 家庭電器製 } \\
\text { 品 }\end{array}$ & $\begin{array}{l}\text { 荒物・金物 } \\
\text { 陶磁器 }\end{array}$ & $\begin{array}{l}\text { 書籍 } \\
\text { 文具 }\end{array}$ \\
\hline グループ 3 & 肌着・下着 & \multicolumn{3}{|l|}{ 婦人・子供服 } \\
\hline グループ4 & 家具・建具 & \multicolumn{3}{|c|}{ レジャー・スポーツ用品 } \\
\hline グループ 5 & 紳士服 & $\begin{array}{l}\text { 靴 } \\
\text { カバン類 }\end{array}$ & \multicolumn{2}{|c|}{$\begin{array}{l}\text { 時計・貴金属 } \\
\text { カメラ }\end{array}$} \\
\hline
\end{tabular}

くと、7市町はこの額において県内の上位を占めていると ともに県内の $5 つ の$ 広域行政圈においても各圈域で上位を 占めていることがあげられる。

\section{4. 商圈および買物消費額流入指数の変化}

\section{（1）品目の分類}

買物調査で対象とした 13 品目には、買物消費額の流動か らみて互いに相関が高い品目が存在していた。そこで買物 消費額の流動データに基づき、クラスター分析を用いて買 物品目を5つのグループに分類した。その分類結果を表一 1 に示す。グループ1は食料品で日常生活の必需品であり、 グループの番号が大きくなるにしたがって買回り品、そし て高級品に分けられている。

\section{（2）商圈の変化}

ここでは、商圈を「居住地 $\mathrm{i}$ は買物先比率が最大の值と なる商業地 $\mathrm{j}$ の商圈に含まれる」と定義する。商圈の推定 にあたっては、クラスター分析により分類した品目別に行 い商業地として選択した 7 市町を対象とする。図一 3 に 1989 年における商圈、図一 4 に 1996 年の商圈を示す。図で は、各市町村が含まれる商圈の中心となる市町を網掛けの パターンによって示したが、網掛けのない無地の町村は自 町村での買物先比率が最大となっていることを意味する。 品目グループ 1 の商圈をみると、1989 年では、徳島市に隣 接する 1 村を除いて、すべての市町村において自市町村内 での買物先比率が最大になっていることがわかる。1996 年 では、1989 年に比心、商業地として設定した 7 市町の商圈 の拡大がみられ、他市町村へ出かける傾向が現れてきたこ とがうかがえる。品目グループ2では、1989 年では、グル 一プ1に比べ、徳島市や池田町の商圈が大きくなっている。 1996 年では、1989 年のグループ2 あるいは 1996 年のグル 一プ 1 と比較すると、阿南市と脇町における商圈の拡大が 著しい。品目グループ3では、1989 年では、グループ 2 と 比べ、それぞれの商圈が少し拡大している。1996 年では、 1989 年と比較すると、ここでも阿南市と脇町における商圈 の拡大が著しい。品目グループ4をみると、1989 年では、 徳島市の商圈は県中央部において大きく拡大しているのが 特徴的である。ところが、1989 年において徳島市の商圈で あった県南部が阿南市の商圈になっている。最後に、品目 グループ5をみると、1989 年では、徳島市の商圈は他のグ ループと比較するとさらに搪大し、県中央部から南部にか けて大きくなっている。1996 年では、1989 年と比較すると 阿南市と脇町の商圈が拡大している。

これら商圈を示した図において、例えば、1996 年の品目 グループ5をみると、南部地域にある町村は近くの商業地 である阿南市よりも、より遠い徳島市の商圈に含まれてい る。これは、買物行動は買物先までの空間的な抵抗と買物 先の魅力度に影響を受けていると考えると、これら市町村 の消費者は、買物先までの距離抵抗に対する魅力度の大き 


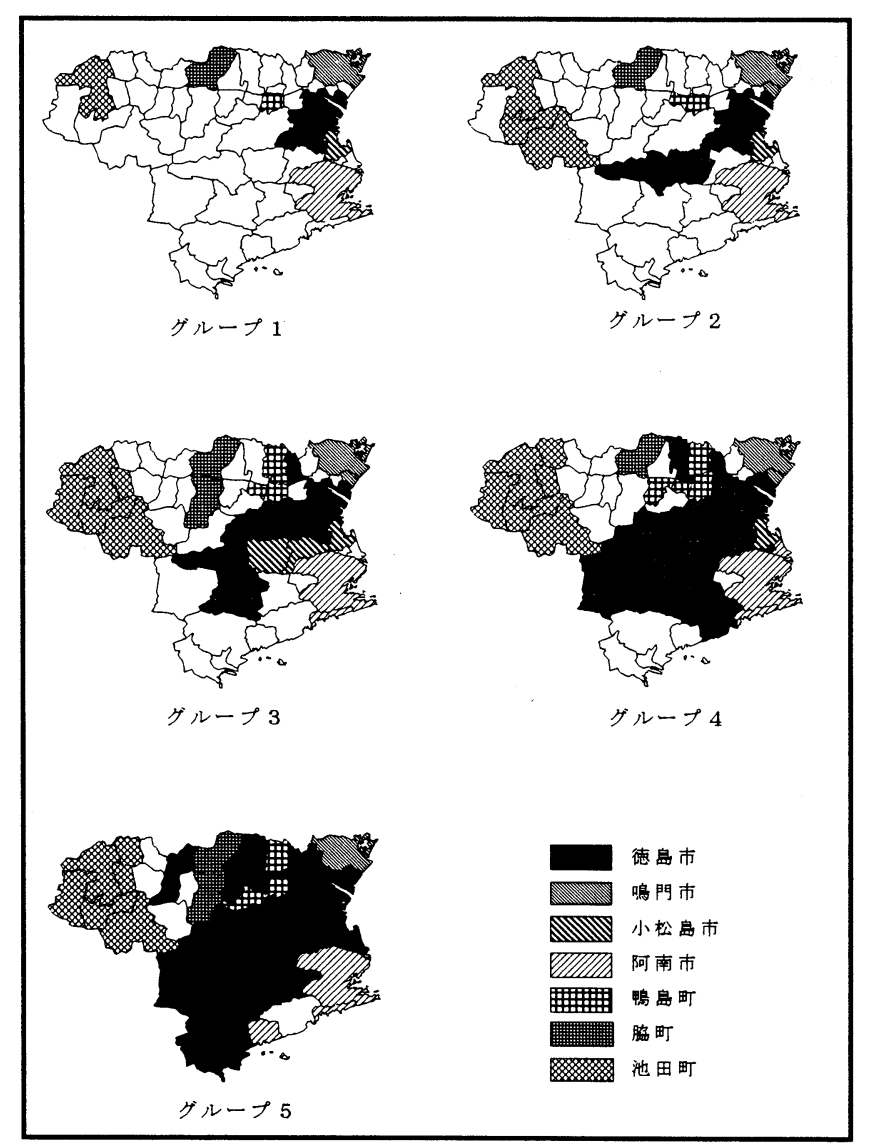

図 -3 品目別の商圈（1989 年）

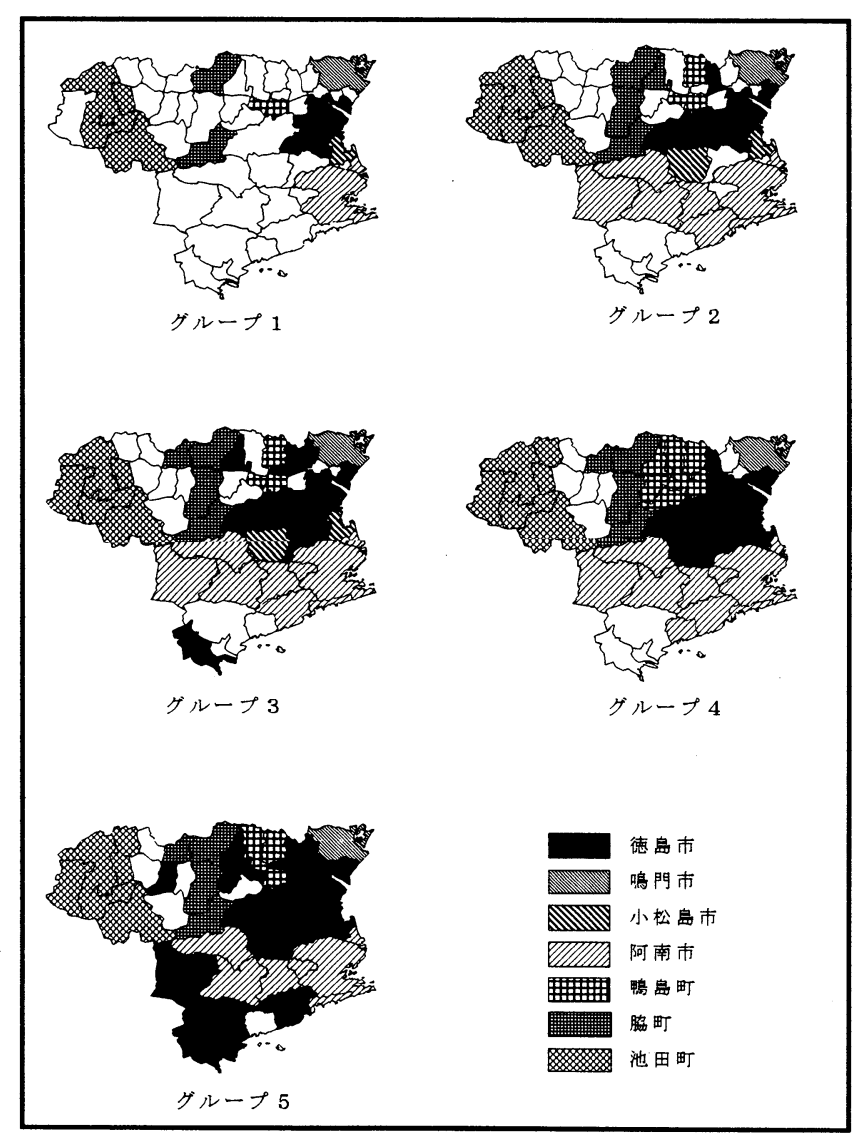

図 -4 品目別の商圈（1996 年）
さに関して徳島市の方が阿南市よりも優れていると考えて いることの現れである。この現象については、後で述べる 買物消費額流動モデルを用いて説明することが可能であり、 そこで再び言及することにする。以上で示したように、地 図を用いた分析によって、商圈の変化を平面的にかつ視覚 的に表すことができた。

（3）商業地における買物総額の変化

代表的な商業地として選んだ 7 市町に着目し、そこへの 買物消費額の流入状況を 1 つ指標として表すために、式 (1) に示すような商業地 $\mathrm{j}$ における買物総額を算出する式 を設定した。

$$
\mu_{j}(m)=\sum_{i}\left\{r_{i j}(m) / 100\right\} \cdot P_{i} \cdot B_{i}(m)
$$

ただし、 $\mu_{\mathrm{j}}(\mathrm{m})$ : 品目グループ mの商業地 $\mathrm{j}$ での買物総額 $r_{i j}(m)$ : 品目グループ mの居住地 $\mathrm{i}$ における買物 消費額の商業地 $\mathrm{j}$ の買物先比率（\%) $\mathrm{P}_{\mathrm{i}}$ : 居住地 $\mathrm{i}$ の人口 (人) $\mathrm{B}_{\mathrm{i}}(\mathrm{m})$ : 品目グループ mの市町村 $\mathrm{i}$ における 1 人当たりの支出額 (円)

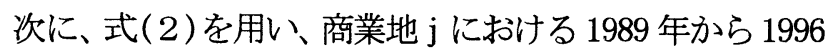
年にかけての買物総額の変化率 $\delta_{\mathrm{j}}(\mathrm{m})$ を各品目について 算出する。ただし、1 人当たりの品目グループ $\mathrm{m}$ の支出額 は市町村間で差がないと仮定した。

$$
\delta_{j}(m)=\frac{\mu_{j}(m, 96)-\mu_{j}(m, 89)}{\mu_{j}(m, 89)}
$$

ただし、 $\delta_{\mathrm{j}}(\mathrm{m})$ : 商業地 $\mathrm{j}$ における品目グループ $\mathrm{m} の$ 買物総額の変化率

$\mu_{\mathrm{j}}(\mathrm{m}, 96)$ : 商業地 $\mathrm{j}$ における品目グループ $\mathrm{m} の$ 1996 年U買物総額

$\mu_{\mathrm{j}}(\mathrm{m}, 89)$ : 商業地 $\mathrm{j}$ における品目グループ $\mathrm{m} の$ 1989 年の買物総額

式(2)で求められた 1989 年から 1996 年にかけての買物 総額の変化率 $\delta_{\mathrm{j}}(\mathrm{m})$ を示したのが、図一 5 である。これ をみると阿南市、鴨島町、脇町で変化率の増加が顕著であ る。一方、徳島市、鳴門市、小松島市の変化は停滞、ある いは減少気味である。この理由として、1989 年から 1996 年にかけて、阿南市と脇町では大規模店舗数がともに 2 倍 以上、また鴨島町では全店舗面積が約 2 割増加したことが あげられる。このように、買物総額を用いた分析によって、 すべての市町村からの各商業地に流れ込む買物消費額の変 化を品目グループ別に明らかにすることができた。 


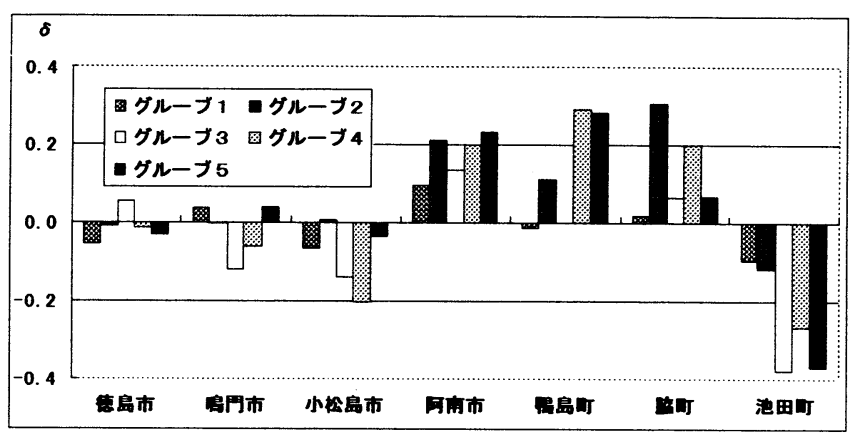

図 -5 買物総額の変化率

\section{5. 行商・通信販売による買物消費額の変化とその要因}

最近の消費者の買物方法の 1 つとして行商や通信販売を 見逃すことはできない。行商・通信販売による買物消費額 の比率が増加すれば、現在問題になっている中心商業地の 売上げの低下や大規模ショッピングセンター八の需要の減 少といった影響を及ぼす可能性がある。また、行商・通信 販売で買物を行えば、買物先までの移動に伴う負担が軽减 されるため、商業地へのアクセシビリティが低い地域では、 行商・通信販売の需要は高いと予想される。このような視 点に立ち、ここでは、買物先として行商と通信販売を対象 とし、本研究の目的である買物消費額流動の変化とその要 因に関する分析を行う。

\section{（1）買物消費額の変化}

図一6は、各市町村における買物消費額のうち、行商と 通信販売で消費されている消費額の比率を、品目グループ 1、3、5について、百分率（\%) で表示したものである。 1989 年、1996 年を比較すると、どの品目をみても、地域全 体で行商・通信販売による買物消費額の比率が增えている ことがわかる。グループ1、グループ3では、1989 年にお ける平均值が $3 \%$ 程度であったのに対し、1996 年ではほと んどすべての市町村で $5 \%$ を越えており、10\%を越える 市町村も山間部に相当する南部と中西部で多くみられる。 また、グループ5においては、1989 年では5\%を越える市 町村はほとんどなかったのに対し、1996 では5\%を越える 市町村が西部から、南部にかけて多くみられる。

行商・通信販売による買物消費額比率の地域間比較を行 うと、総じて南部と中西部で高い比率を示している。これ らの地域は、山間地域であり、買物の利便性が低い地域で ある。

\section{（2）買物消費額の影響要因}

行商・通信販売による買物消費額の地域や年次による違 いを説明するため、その影響要因と考えられる地域の社会 経済指標との相関分析を行ったところ、式 (3)に示寸買物 におけるアクセシビリティ指標と買物消費額の関連におい て特徴がみられた。その結果を表一 2 に示す。

$$
A_{i}(m)=\sum_{j} \frac{S_{j}(m)}{t_{i j}}
$$

ただし、 $\mathrm{A}_{\mathrm{i}}(\mathrm{m})$ : 居住地 $\mathrm{i}$ における品目 $\mathrm{m} の$

アクセシビリティ

$\mathrm{S}_{\mathrm{j}}(\mathrm{m})$ : 商業地 $\mathrm{j}$ における品目 $\mathrm{m}$ の店舗数

$\mathrm{t}_{\mathrm{ij}}$ : 居住地 $\mathrm{i}$ と商業地 $\mathrm{j}$ との時間距離

表ー 2 をみると買物の利便性を表すアクセシビリティ指 標と行商・通信販売による買物消費額は、1989年に比べ1996 年で負の相関が強くなっている。また、品目では、日常品 よりも買回り品や高級品の方が負の相関が強い。つまり、 買物の利便性の低い山間地になるほど、行商や通信販売に よる買物消費額の比率が高いことが示されている。

この結果を裏付けるために、全品目に関するアクセシビ リティ指標を図ー 7 に示した。表 -2 は品目別の相関分析 結果であるが、各品目のアクセシビリティ指標間の相関係 数をみると、どの品目間も互いに 0.970 以上と相関が強か ったため、全品目のアクセシビリティ指標を描いた図ー 7 は、買物の利便性をほぼ表していると考えてよい。この図 -7 と先の図一 6 から、これまでに述べてきた買物の利便 性と行商・通信販売による買物消費額の関係を視覚的に把 握することができる。

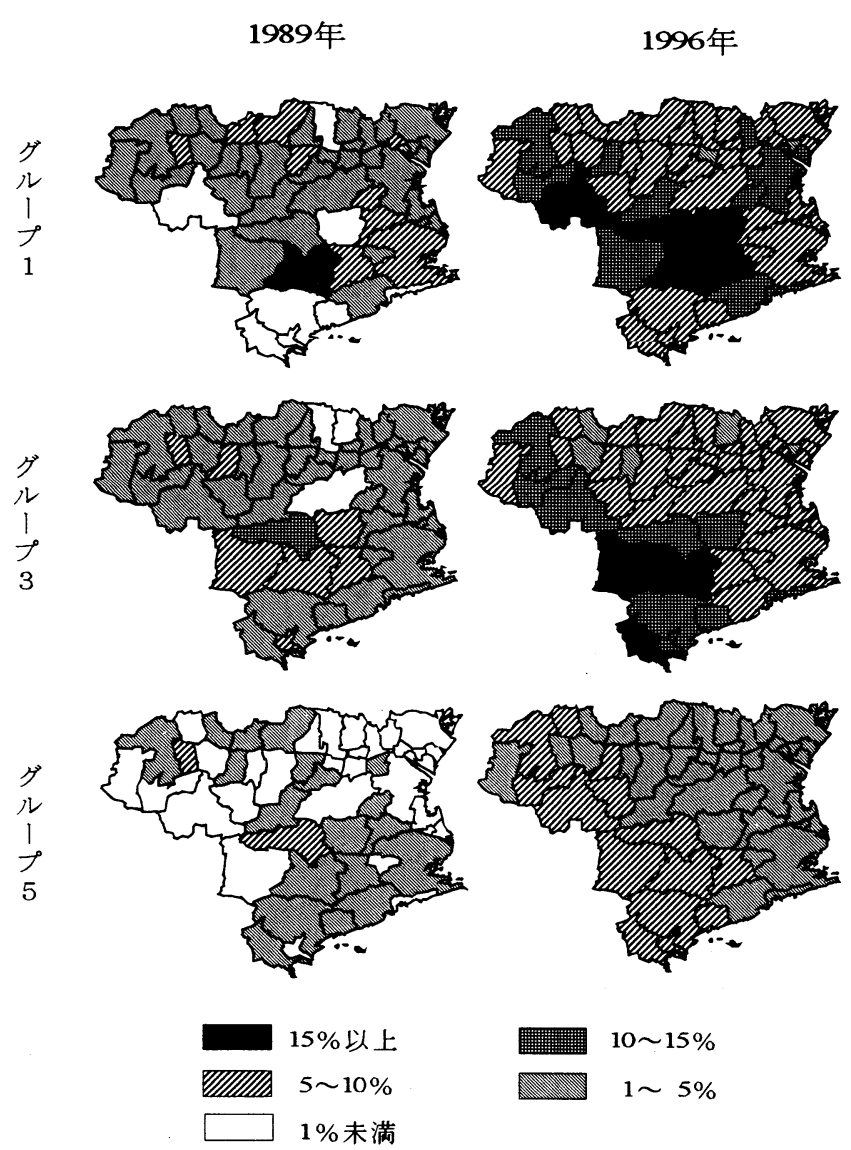

図-6 各市町村の行商・通信販売による買物消費額比率 
表-2 行商・通信販売による買物消費額比率と

アクセシビリティの相関係数

\begin{tabular}{|c|c|c|c|c|c|c|}
\hline & グループグループグループグループグループ & 全体 \\
& 1 & 2 & 3 & 4 & 5 & \\
\hline 1989年 & 0.004 & -0.079 & -0.261 & -0.313 & -0.361 & -0.054 \\
\hline 1996年 & -0.455 & -0.570 & -0.532 & -0.612 & -0.691 & -0.555 \\
\hline
\end{tabular}

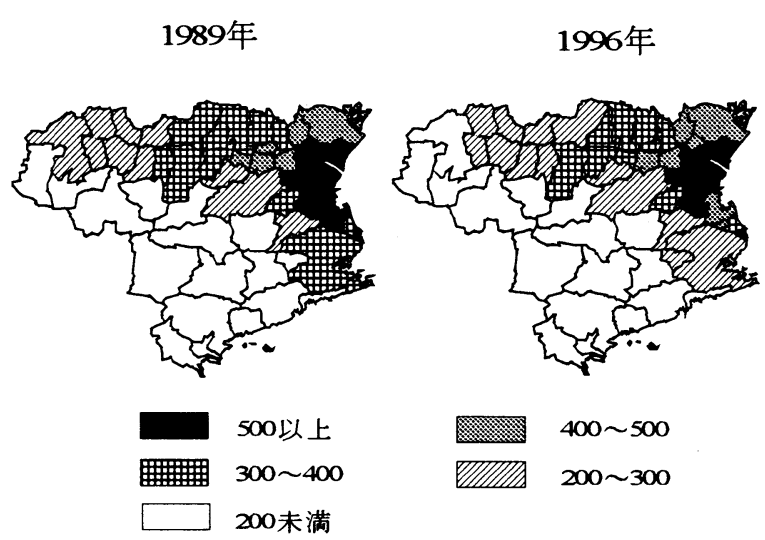

図 -7 買物のアクセシビリティ

\section{6. 買物消費額の流動モデルによる買物行動分析}

（1）買物消費額の流動モデル3)

居住地 $\mathrm{i}$ に住む人は、総予算内で買物により得られる効 用を最大にするように買物先 $\mathrm{j}$ での買物回数と買物額を決 定すると仮定する。この問題は、次の式 (4)、(5)のよう に定式化することができる。

$$
\begin{aligned}
& U_{i}=\sum_{j}{s_{i j}{ }^{\alpha} \cdot n_{i j}{ }^{\beta} \cdot Z_{j}}^{\geq \sum_{j} n_{i j} \cdot s_{i j}+\sum_{j} n_{i j} \cdot c_{i j}}
\end{aligned}
$$

ただし、 $U_{i}$ : 居住地 $\mathrm{i}$ の消費者が買物によって得る 効用

$\mathrm{s}_{\mathrm{ij}}$ : 居住地 $\mathrm{i}$ の消費者が商業地 $\mathrm{j}$ で行う 1 回 の買物における消費額

$\mathrm{n}_{\mathrm{i} j}$ : 居住地 $\mathrm{i}$ の消費者がある期間において 商業地 $\mathrm{j}$ で買物をする回数

$\mathrm{Z}_{\mathrm{j}}$ : 商業地 $\mathrm{j}$ の魅力度

$\mathrm{I}_{\mathrm{i}}$ ：居住地 $\mathrm{i}$ の消費者の買物予算額

$\mathrm{c}_{\mathrm{i} j \mathrm{j}}$ : 居住地 $\mathrm{i}$ から商業地 $\mathrm{j}$ までの交通費用

$\alpha 、 \beta$ : パラメータ $(0<\alpha<1 、 0<\beta<1)$

すなわち、消費者は、より魅力度の高い商業地を多く訪 れ、買物に消費できる予算額以内で沢山の買物をすること によって、より高い効用を得ることになる。商業地の魅力 とは、商業地が買物客を引きつける要因、つまり小売店数、 売場面積、駐車台数などの規模に関する要因や品揃え、品 質、営業時間といった質的な要因によって規定されるもの
である。

式(4)のU $\mathrm{U}_{\mathrm{i}}$ を最大化する $\mathrm{n}_{\mathrm{i}}$ はラグランジェの未定乗 数法によって求められ、さらに、居住地 $\mathrm{i}$ から商業地 $\mathrm{j}$ 一 の買物消費額の流動 $\mathrm{x}_{\mathrm{i} j}$ は、 $\mathrm{x}_{\mathrm{i} j}=\mathrm{n}_{\mathrm{i} j} \cdot \mathrm{s}_{\mathrm{i} j}$ であること から次の式(6)が導かれる。

$$
x_{i j}=\frac{\alpha}{\beta} \frac{I_{i} \cdot Z_{j}^{\frac{1}{1-\beta}} \cdot\left(\frac{1}{c_{i j}}\right)^{\frac{\beta-\alpha}{1-\beta}}}{\sum_{j} Z_{j}^{\frac{1}{1-\beta}} \cdot\left(\frac{1}{c_{i j}}\right)^{\frac{\beta-\alpha}{1-\beta}}}
$$

すなわち、居住地 $\mathrm{i}$ の消費者が、商業地 $\mathrm{j}$ で、ある期間 に消費する買物消費額 $\mathrm{x}_{\mathrm{i} i \mathrm{j}}$ は、すべての買物とそれに伴う 交通費用のための総予算 $\mathrm{I}_{\mathrm{i}}$ のうち、効用関数のパラメータ の比 $(\alpha / \beta)$ 分を各商業地 $\mathrm{j}$ に割り振る構造となってい る。居住地 $\mathrm{i}$ において $(\alpha / \beta) \mathrm{I}_{\mathrm{i}}$ が商業地 $\mathrm{j}$ に割り振ら れる比率は、商業地 $\mathrm{j}$ の魅力度 $Z_{\mathrm{j}}$ の $1 /(1-\beta)$ 乗に比 例し、商業地 $\mathrm{j}$ までの交通費用 $\mathrm{c}_{\mathrm{i}} \mathrm{j}$ の $(\beta-\alpha) /(1-$ $\beta$ ）乗に反比例することになる。

ここで、式(6)を用いて先に述べた商圈の説明を行う。 商圈の定義は先に述べたとおりとし、任意の 2 つの商業地 $\mathrm{A}$ と B 想定すると、これら両商業地の商圈の境界は式 (6) から、 $\mathrm{x}_{\mathrm{PA}}=\mathrm{x}_{\mathrm{PB}}$ を満たす点 $\mathrm{P}$ 結んだ線上にある。 つまり、両商業地の魅力度を $\mathrm{Z}_{\mathrm{A}}$ と $\mathrm{Z}_{\mathrm{B}}$ 、点 $\mathrm{P}$ から両商業地 への交通費用を $\mathrm{c}_{\mathrm{PA}} 、 \mathrm{c}_{\mathrm{PB}}$ とすると、商圈の境界線上では 式( 7 )が成り立つ。

$Z_{A} \frac{1}{1-\beta} \cdot\left(\frac{1}{c_{P A}}\right)^{\frac{\beta-\alpha}{1-\beta}}=Z_{B}^{\frac{1}{1-\beta}} \cdot\left(\frac{1}{c_{P B}}\right)^{\frac{\beta-\alpha}{1-\beta}}$

したがって、ある任意の市町村 $\mathrm{i}$ について、式(7)の右 辺の值と左辺の值をそれぞれ計算し、それらを比較するこ とによって市町村 $\mathrm{i}$ がどちらの商業地の商圈に含まれてい るかを判定することができる。つまり、左辺の值が右辺の 值より大きければ市町村 $\mathrm{i}$ は商業地 $\mathrm{A}$ の商圈に含まれ、逆 の場合は Bの商圈に含まれることになる。この商圈の判定 は、商業地 $\mathrm{A}$ と Bの間の市町村のみならず、これらの商業 地の背後にある市町村にも適用することが可能である。

仮に、商業地 $\mathrm{A}$ の魅力度 $Z_{\mathrm{A}}$ が商業地 $\mathrm{B}$ の魅力度 $Z_{\mathrm{B}}$ より も大きいとすると、交通費用と距離が線形関係にあるなら ば、商業地 $\mathrm{B}$ の商圏は商業地 $\mathrm{B}$ を囲む円になり、商業地 $\mathrm{A}$ の商圈はその他のエリアになる。したがって、この場合に は、商業地 $\mathrm{A}$ の商圈に含まれる市町村が商業地 $\mathrm{B}$ の背後に 存在することになる。先の商圈の図に示した 1996 年の品目 グループ5で、南部地域にある町村が近くにある阿南市よ りも、より遠い徳島市の商圈に含まれている現象は、以上 のことから説明できる。なお、この説明の詳細については、 
既往研究を参考にすることができる ${ }^{4)}$ 5)。

以下では、式 (6)に示した買物消費額の流動モデルを用 いて、消費者の買物行動を分析する。消費者の買物モデル については従来から多くのモデルが提案され、また概観さ れている6７７８。小売り買物研究において最も早く貢献し たのがライリーの小売り引力の法則である ${ }^{9)}$ 。ライリーは、 都市の買物センターの吸引力をグラビティタイプの式で表 し、都市間の任意の地点におけるそれら両都市への吸引力 の比率を分析した。八フは、小売りグラビティモデルをさ らに発展させ、確率論的な小売り買物モデルを提案した。 ライリーの法則やハフのモデルは現象を非常によく説明す ることができたが、経験則であり、理論的な裏付けや行動 学的な説明が行われていなかった。本研究の分析で用いる モデルも、グラビティタイプのモデルであるが、消費者の 効用最大化行動に基づくモデルであり、理論的な裏付けや 行動学的な説明を行うことができる。ここで、本研究で式 （6）に示寸モデルを用いた理由について若干の説明を行う。 まず、対象地域内は市町村の役所や学校などを核に比較的 まとまった集落を形成している町村が多く、また集落間は 住居が連たんしていないことがあげられる。また、地域内 で商業中心となっている市町への買物構造を買物流動額か ら明確にするという目的に対して、用いるモデルは構造が シンプルでかつ経験的に説明力が高いとされている。さら に、式(6)に示すモデルは消費者の居住地から買物先まで の費用を説明変数に含んでいることから、このモデルの使 用により、交通条件と買物行動の関連の分析も行うことが できる。

（2）モデルのパラメータの推定方法 ${ }^{100}{ }^{11}$

居住地 $\mathrm{i}$ から商業地 $\mathrm{j}$ と $\mathrm{k}$ への買物を対象にし、式(6) で与えられるそれぞれの商業地への買物消費額の比をとる ことによって次の式(8)を得る。

$$
\frac{x_{i j}}{x_{i k}}=\left(\frac{Z_{j}}{Z_{k}}\right)^{\frac{1}{1-\beta}} \cdot\left(\frac{c_{i k}}{c_{i j}}\right)^{\frac{\beta-\alpha}{1-\beta}}
$$

式(8)の両辺の対数をとると線形化することができ、重 回帰分析によってパラメータを推定することができる。

モデルによるパラメータの推定にあたって、商業地 $\mathrm{j}$ の 魅力度 $Z_{j}$ として、次の 2 つの魅力度関数式を設定する。

(1) $Z_{j}=S_{j n}{ }^{a} \cdot L_{j}{ }^{b} \cdot Q_{j}^{c}$

(2) $Z_{j}=\exp \left(a S_{j n}+b L_{j}+c Q_{j}\right)$

ただし、 $\mathrm{S}_{\mathrm{j} 1}$ : 商業地 $\mathrm{j}$ における小売店数 $(\mathrm{n}=1)$ $\mathrm{S}_{\mathrm{j} 2}$ : 商業地 $\mathrm{j}$ における売場面積 $(\mathrm{n}=2)$
$\mathrm{S}_{\mathrm{j} 3}$ : 商業地 $\mathrm{j}$ における従業者数 $(\mathrm{n}=3)$

$\mathrm{L}_{\mathrm{j}}$ : 商業地 $\mathrm{j}$ におけ引遊與娛楽施設数

$\mathrm{Q}_{\mathrm{j}}$ : 商業地 $\mathrm{j}$ における駐車台数

$a 、 b 、 c:$ パラメータ

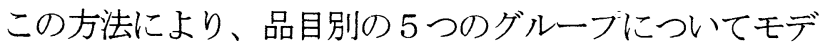
ル推定を行った。ここで、居住地 $\mathrm{i}$ から商業地 $\mathrm{j} へ の$ 交通 費用 $\mathrm{c}_{\mathrm{i}}$ 仗道路利用による時間距離 $\mathrm{t}_{\mathrm{i}}$ に比例すると仮定 し、比例定数 $\mathrm{k}$ を用いて交通費用 $\mathrm{c}_{\mathrm{ij}}$ を次の式 (11) で求 めた。ただし、居住地 $\mathrm{i}$ から商業地 $\mathrm{j} へ の$ 移動において鉄 道が利用可能な場合は、道路のみの場合に比へ、道路利用 における時間距離と費用の関係に違いがあるとの仮定から、 鉄道利用の有無に関するダミー変数を導入した。

$$
c_{i j}=k t_{i j} \cdot \gamma^{R i j}
$$

ただし、 $R_{i j}$ ：居住地 $\mathrm{i}$ から商業地 $\mathrm{j}$ の間で、鉄道が利用 可能な場合は 1 、そうで無い場合は 0 とな るダミー変数

$\mathrm{k} 、 \gamma:$ バラメータ

商業地の魅力度を表す要因として小売店数、売場面積、 従業者数、遊興娛楽施設数、駐車台数を取り上げ、魅力度 関数の変数とした。しかしながら、これら変数間の相関係 数をみると、すべての変数相互間で 0.950 以上の值を示し、 非常に強い相関関係が認められた。したがって、魅力度関 数にはすべての変数を同時に使用することは統計上問題が あるため、各変数を個々に用いて魅力度関数を推定した。 ところで、商業地の魅力度は、このほかにも品揃え、品質、 営業時間といった様々な要因によっても左右されるが、主 要かつデータ収集が可能な要因を採用した。

\section{（3）パラメータの推定結果と考察}

モデルのパラメータの推定結果を表ー 3 と表一 4 に示す。 表一 3 は魅力度関数に式 (9)、表一 4 は式(10)を用いた結 果である。表においてG 1～G 5 は品目によるグルーブを 表す。商業地域の魅力度に関する変数怯、先述のように同 時にモデルに取り入れることができないため、各変数それ ぞれについてモデルを作成したが、そのうち、小売店数を 用いた場合の結果を示す。なお、鉄道利用の有無に関する 係数は $5 \%$ 検定により $\mathrm{t}$ 值が低いものを削除した。また、 表において、小売店数のパラメータは式 (6) と式 (9) およ び(10)の係数である $\mathrm{a} /(1-\beta)$ の值を、時間距離のパ ラメータは式(6)の $(\beta-\alpha) /(1-\beta)$ の值を示して いる。

以上の結果をみると、魅力度関数の違いによるモデルの 精度への影響はほとんどみられない。また、各変数のパラ メータの符号は妥当であり、 $\mathrm{t}$ 值をみると鉄道の有無に関 する係数の $\mathrm{t}$ 值がやや小さいものの、小売店数および時間 
表一 3 パラメータ推定結果(1)

\begin{tabular}{|c|c|c|c|c|c|c|c|c|c|c|c|}
\hline 年 & グループ & \multicolumn{2}{|c|}{ G 1} & \multicolumn{2}{|c|}{ G 2} & \multicolumn{2}{|c|}{ G 3} & \multicolumn{2}{|c|}{ G 4} & \multicolumn{2}{|c|}{ G 5} \\
\hline \multirow{6}{*}{1989} & サンプル数 & & 78 & & 77 & & 77 & & 77 & & 77 \\
\hline & 決定係数 & & 0.739 & & 0.755 & & $\overline{0.674}$ & & 0.688 & & 0.726 \\
\hline & & 係数 & $\mathrm{t}$ 值 & 係数 & $\mathrm{t}$ 值 & 係数 & $\mathrm{t}$ 值 & 係数 & $\mathrm{t}$ 值 & 係数 & $\mathrm{t}$ 值 \\
\hline & 小売店数 & 0.979 & 8.346 & 1.138 & 12.608 & 1.169 & 12.038 & 1.683 & 12.699 & 1.471 & 12.952 \\
\hline & 時間距離 & 3.065 & 13.774 & 2.635 & 14.416 & 2.401 & 11.243 & 2.745 & 11.181 & 2.275 & 9.591 \\
\hline & $\mathrm{J} \mathrm{R}$ & -0.867 & -2.239 & -0.832 & -2.613 & - & - & - & - & -1.080 & -2.576 \\
\hline \multirow{6}{*}{1996} & サンプル数 & & 82 & & 82 & & 82 & & 82 & & 82 \\
\hline & 決定係数 & & 0.728 & & 0.727 & & 0.595 & & 0.696 & & 0.708 \\
\hline & & 係数 & $\mathrm{t}$ 值 & 係数 & $\mathrm{t}$ 值 & 係数 & $\mathrm{t}$ 值 & 係数 & $\mathrm{t}$ 值 & 係数 & $\mathrm{t}$ 值 \\
\hline & 小売店数 & 0.507 & 4.393 & 0.753 & 9.305 & 0.728 & 9.607 & 1.121 & 11.443 & 1.076 & 12.730 \\
\hline & 時間距離 & 2.781 & 11.982 & 2.452 & 13.980 & 1.619 & 9.177 & 2.259 & 12.294 & 1.692 & 9.674 \\
\hline & $\mathrm{JR}$ & - & - & -0.586 & -2.017 & -0.667 & -2.146 & -0.807 & -2.620 & -0.954 & -3.088 \\
\hline
\end{tabular}

表ー4 パラメータ推定結果(2)

\begin{tabular}{|c|c|c|c|c|c|c|c|c|c|}
\hline 年 & グルーブ & $\mathrm{G}$ & & $\mathrm{G}$ & & $G$ & & G 4 & G 5 \\
\hline \multirow{6}{*}{198} & サンプル数 & & 78 & & 77 & & 77 & 77 & $\overline{777}$ \\
\hline & 決定係数 & & 0.718 & & 0.746 & & 0.686 & 0.704 & 0.713 \\
\hline & & 係数 & $\mathrm{t}$ 值 & 係数 & $\mathrm{t}$ 值 & 係数 & $\mathrm{t}$ 值 & $\mathrm{t}$ 值 & $\mathrm{t}$ 值 \\
\hline & 小売店数 & 0.124 & 7.676 & 0.301 & 12.282 & 0.559 & 11.609 & 12.376 & 1.066 \\
\hline & 時間距離 & 2.841 & 13.197 & 2.421 & 13.946 & 2.177 & 11.037 & 10.930 & 8.824 \\
\hline & $\begin{array}{ll}J R \\
\end{array}$ & -1.063 & -2.664 & -0.985 & -3.053 & -0.903 & -2.447 & \begin{tabular}{r|r|r|}
0.972 & -2.411 \\
\end{tabular} & $-1.255-2.940$ \\
\hline \multirow{6}{*}{1996} & サンプル数 & & 82 & & 82 & & 82 & 82 & $\begin{array}{ll} \\
\end{array}$ \\
\hline & 決定係数 & & 0.714 & & 0.716 & & 0.570 & 0.678 & 0.683 \\
\hline & & 係数 & $\mathrm{t}$ 值 & 係数 & $\mathrm{t}$ 值 & 係数 & $\mathrm{t}$ 值 & $\mathrm{t}$ 值 & $\mathrm{t}$ 值 \\
\hline & 小売店数 & 0.066 & 3.800 & 0.210 & 8.955 & 0.381 & 9.075 & \begin{tabular}{l|l}
1.097 & 10.928 \\
\end{tabular} & 11.952 \\
\hline & 時間距離 & 2.621 & 11.707 & 2.251 & 13.753 & 1.479 & 8.545 & \begin{tabular}{l|l}
2.036 & 11.610 \\
\end{tabular} & 1.551 \\
\hline & $\mathrm{J} \mathrm{R}$ & - & & -0.680 & -2.309 & -0.823 & -2.590 & $-1.011 \mid-3.224$ & \begin{tabular}{l|l|l}
-0.992 & -3.084 \\
\end{tabular} \\
\hline
\end{tabular}

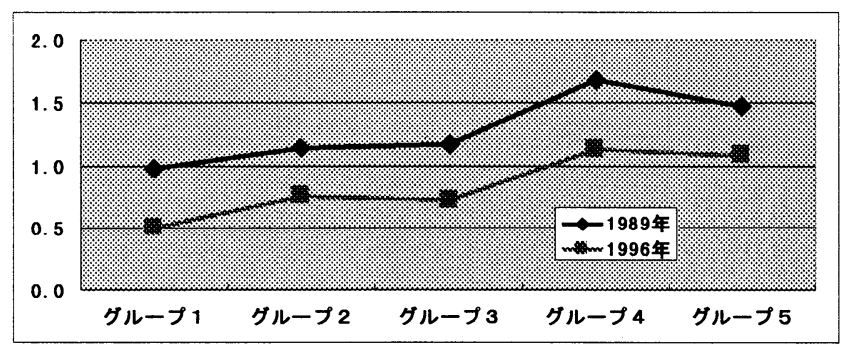

図-8 小売店数のパラメータの変化

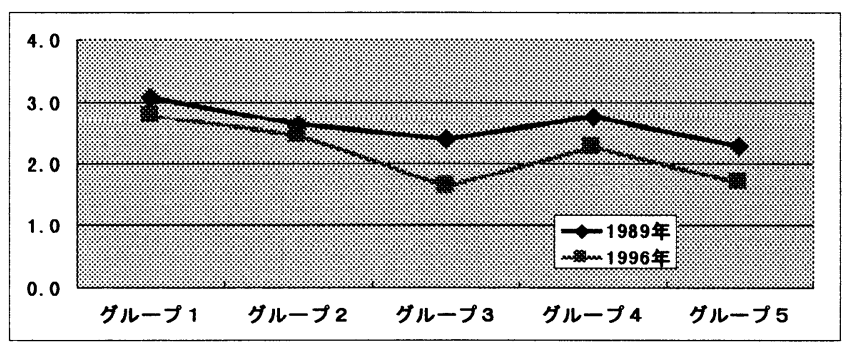

図-9 時間距離のパラメータの変化

距離の $\mathrm{t}$ 值は大きく、意味のある変数となっている。品目 グループ別にパラメータを比較すると、グループ4を除き、 グループ1からグループ 5 になるにしたがって、小売店数 の值が大きくなっている。これにより、買物品目が日常品 から、買回り品、高級品になるにしたがって購入先の魅力 度から受ける影響が強くなっていることがわかる。一方、 時間距離のパラメータをみると、グループ 4 を除いて日常 品から買回り品になるにしたがって、距離抵抗が小さくな
っている。買回り品に比心゙、日常品のように、同じような 品物が比較的どこでも手に入るような場合は、買物先まで の時間により影響を受けることがわかった。また、鉄道 ( J R）のパラメータから式（11）の $\gamma$ を求めると、多少のば らつきがあるもののほぼ $0.6 〜 0.8$ の值となり、買物 に鉄道（J R）を利用できる場合は、できない場合に比べ 交通負担が割り引かれる結果となっている。

次に、小売店数と時間距離のパラメータを図ー8 と図ー 9 に示す。これらの值を 1989 年と 1996 年の間で比較する と各品目において、1989 年から 1996 年にかけて、小売店数、 時間距離ともにパラメータの值が小さくなっている。つま り、買物消費額の流動においては小売店数の違いから受け る影響、時間距離の長短から受ける影響は、ともにより小 さくなっていると解釈することができる。この結果より、 消費者の買物は多様化してきたと推察される。

\section{7.おわりに}

本研究では、住民の買物行動を買物消費額の流動によっ てとらえ、地方圈において市町村間の品目別の買物消費額 流動や商圈がどのように変化しているのかを明らかにした。 また、買物消費額の流動モデルを用いて、買物消費額流動 に及ぼす影響要因を把握した後、その変化についても考察 を行った。本研究で得られた主な成果を以下にまとめる。

（1）買物品目の分類を行い、消費総額の流出率の変化、 
品目別の商圈の変化を明らかにした。この結果、日常頻繁 に購入する品目においては、主に自市町村内で買物が行わ れていること、買回り品から高級品になるほど地域の核と なる市町で買物が行われる傾向が強くなることがわかった。

（2）買物の利便性を表すアクセシビリティ指標と行商・ 通信販売による買物消費額の関係をみると、1989 年に比べ 1996 年で負の相関が強くなっていること、また、品目では、 日常品よりも買回り品や高級品の方が負の相関が強いこと がわかった。これによって、買物の利便性の低い山間地に なるほど、行商や通信販売による買物消費額の比率が高い ことを明らかにすることができた。

（3）買物消費額の流動モデルを用い、5つの品目グルー プについてモデル推定を行ったところ、全体的にみて満足 のいく結果が得られた。また、日常の買物品から買回り品 や高級品になるにしたがって、購入先の魅力度から受ける 影響が強くなっていること、一方、時間距離による影響は 逆に弱くなっていることがわかった。さらに、年次的の変 化とともに、購入先の魅力度の違いから受ける影響、時間 距離の長短から受ける影響は、ともにより小さくなってい ることも明らかにされた。

以上、本研究のテーマとした地方圏における買物消費額 流動の変化とその要因に関する分析のまとめを述べたが、 本研究で用いた買物消費額から導かれた種々の指標や商圈、 さらに時系列分析や買物消費額の流動モデルは、これらの 成果を得るために大いに貢献したと考えている。

筆者らは、さらに、旧来からある都市内の商店街と郊外 立地型のショッピングセンターへの買物行動をよりミクロ
に分析し、中心市街地の衰退問題と活性化策に関する研究 を展開していきたいと考えている。そのためにはまず地方 圈全体における買物構造とその近年の変化を明らかにする ことが必要であると考えていたが、本研究の成果から、こ の視点での目的を達成できたと考えている。

\section{[参考文献]}

1) 徳島県商工労働部経営金融課: 平成元年度徳島県商業 コミュニティプラン事業報告書, 平成 2 年.

2) 徳島県商工労働部経営金融課 : 平成 8 年度徳島県商業 コミュニティプラン事業報告書，平成 9 年.

3）近藤光男，廣瀬義伸：効用最大化に基づく買物行動モ デルとその地方圈への適用に関する研究，都市計画論 文集，No. 32，pp.91-96， 1997.

4）青山吉隆, 近藤光男: 買物行動モデルと商圈の理論的 研究, 地域学研究, Vol. 17, pp. 55〜69, 1987.

5）近藤光男 : 高速道路の整備が商圈に及ぼす影響, 高速 道路と自動車，第 35 巻，第 4 号， 1992 .

6) Foot, D. : Operational Urban Models, Methuen, 1981.

7）上掲 4)

8）例えば, 森地茂, 屋井鉄雄, 藤井卓, 竹内研一：買回 品の買物行動における商業地選択分析, 土木計画学研 究・論文集, Vol. 1, pp. 27〜34，1984.

9）西岡久雄, 鈴木安昭, 奥野隆史（共訳）：小売業・サ一 ビス業の立地，大明堂，1982。

10 ）徳島県企画調整部統計課 : 徳島県の商業, 昭和 63 年. 11 ) 徳島県企画調整部統計課 : 徳島県の商業, 平成 6 年.

地方圈における買物消費額流動の変化とその要因に関する分析

近藤光男，花岡憲司，廣瀬義伸，青木 聡

本研究では、住民の買物行動を買物消費額の流動によってとらえ、地方圈において市町村間の品目別の買物消費額 流動や商圈がどのように変化しているのかを明らかにした。また、買物消費額の流動モデルを用いて、買物消費額流 動に及ぼす影響要因とその変化の分析も行った。その結果、日常頻繁に購入する品目においては、主に自市町村内で 買物が行われていること、買回り品から高級品になるほど地域の核となる市町で買物が行われる傾向が強くなること がわかった。また、モデル分析により、年次的な変化とともに、購入先の魅力度の違いから受ける影響、時間距離の 長短から受ける影響は、ともにより小さくなっていることも明らかにされた。

Change in Money Flow of Shopping Consumption and its Factors in Local Region

By Akio Kondo, Kenji Hanaoka, Yoshinobu Hirose and Satoru Aoki

In this study, changes in the shopping behavior in recent years are analyzed by using data of money flow in shopping consumption. As a result, everyday items are purchased mainly in cities and towns where the consumers live, and that the farther away from being daily necessities and more expensive the items become, the more shopping is done in the established shopping places of major cities and towns. Further, we learned that the influence of the attractiveness of shopping places and of the travel time has both weakened over the years from the results of analysis using a shopping behavioral model. 